\title{
Gentamicin collagen sponges for the prevention of sternal wound infection: A meta-analysis of randomized controlled trials
}

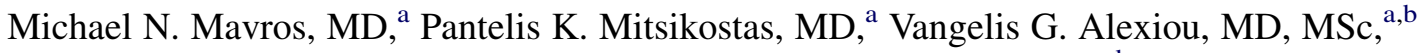 \\ George Peppas, MD, PhD, ${ }^{\mathrm{a}, \mathrm{c}}$ and Matthew E. Falagas, MD, MSc, DSc $\mathrm{c}^{\mathrm{a}, \mathrm{d}, \mathrm{e}}$
}

Objective: The study objective was to determine whether the application of gentamicin collagen sponges reduces sternal wound infections in patients undergoing cardiac surgery.

Methods: A meta-analysis of randomized controlled trials was performed.

Results: Four randomized controlled trials were eligible for inclusion. By pooling data from 4 randomized controlled trials (4672 per-protocol patients), gentamicin collagen sponges reduced deep sternal wound infections (risk ratio, 0.62; 95\% confidence interval, 0.39-0.97) and any sternal wound infections (risk ratio, 0.61; confidence interval, 0.39-0.98). In contrast, no benefit was demonstrated regarding superficial sternal wound infections (4 randomized controlled trials [4672 patients]; risk ratio, $0.65 ; 95 \%$ confidence interval, $0.34-1.25$ ) and all-cause mortality ( 3 randomized controlled trials [3994 patients]; risk ratio, 0.90; 95\% confidence interval, 0.57-1.42). On the basis of data from 2 randomized controlled trials (3410 patients), gentamicin collagen sponges also seemed to reduce surgically treated sternal wound infections (risk ratio, $0.59 ; 95 \%$ confidence interval, 0.41-0.86). The most commonly isolated pathogens were coagulase-negative Staphylococcus spp (43\%) and Staphylococcus aureus (28\%).

Conclusions: Gentamicin collagen sponges seem to reduce the sternal wound infection rate in patients undergoing cardiac surgery. The statistical heterogeneity among the existing trials underlines the need for additional large, high-quality randomized controlled trials. (J Thorac Cardiovasc Surg 2012;144:1235-40)

Sternal wound infections (SWIs) after open cardiac surgery are relatively common and potentially grave complications, with significant associated costs. ${ }^{1-3}$ Risk factors include diabetes, obesity, smoking, hemodynamic instability, transfusions, reoperation, prolonged operative time, prolonged ventilation, type of operation, and others. ${ }^{2,4-6}$ Although antimicrobial prophylaxis is routinely administered, SWIs remain a major threat, leading surgeons to seek additional preventive measures. Gentamicin collagen sponges (GCSs) were developed to provide high local antibiotic concentrations in the wound, with low serum values, thus preventing systemic adverse events (mainly nephrotoxicity). GCSs have been widely used for the prevention and treatment of surgical site infections since 1985; however, no consensus regarding their use in patients undergoing cardiac surgery has been reached.

\footnotetext{
From the Alfa Institute of Biomedical Sciences, ${ }^{\text {a }}$ Athens, Greece; Department of Surgery, ${ }^{\text {b }}$ Kettering General Hospital, Kettering, United Kingdom; Department of Medicine and Infectious Diseases, ${ }^{\mathrm{c}}$ Mitera General Hospital, Hygeia Group, Athens, Greece; Department of Medicine, ${ }^{\mathrm{d}}$ Henry Dunant Hospital, Athens, Greece; and Department of Medicine, ${ }^{\mathrm{e}}$ Tufts University School of Medicine, Boston, Mass.

Disclosures: Authors have nothing to disclose with regard to commercial support.

Received for publication Sept 16, 2011; revisions received Jan 31, 2012; accepted for publication June 15, 2012; available ahead of print July 23, 2012.

Address for reprints: Matthew E. Falagas, MD, MSc, DSc, Alfa Institute of

Biomedical Sciences, 9 Neapoleos St, 15123 Marousi, Athens, Greece (E-mail: m.falagas@aibs.gr).

$0022-5223 / \$ 36.00$

Copyright (c) 2012 by The American Association for Thoracic Surgery

http://dx.doi.org/10.1016/j.jtcvs.2012.06.040
}

The first 2 randomized controlled trials (RCTs) evaluating the effectiveness of GCSs in patients undergoing cardiac surgery were published in 2005 . The study by Friberg and colleagues $^{7}$ (2000 patients, Sweden) reported significantly lower SWI rates in the arm receiving GCSs, whereas the study by Eklund and colleagues ${ }^{8}$ (542 patients, Finland) failed to do so; this was attributed to inadequate sample size. In 2010, a multicenter RCT from 48 US centers (1502 patients) reported no difference in SWI rates between the 2 patient arms ${ }^{9}$; this finding became the subject of heated debate. ${ }^{10-12}$ An additional RCT from Germany (800 patients) recently was performed (the first one to use placebo collagen sponges in the control arm), again claiming that GCSs significantly reduced SWI. ${ }^{13}$ The contradictory findings of the existing trials preclude safe conclusions regarding the effectiveness of GCSs in patients undergoing cardiac surgery. In this context, we sought to systematically review the available published evidence and synthesize the relevant data using the methodology of meta-analysis.

\section{MATERIALS AND METHODS \\ Literature Search}

A systematic search of the literature was performed on PubMed, Scopus, and clinicaltrials.gov databases in September 2011. The applied search pattern was (gentamicin OR aminoglycoside) and (carrier OR material OR sponge OR implant or collagen) and (cardiac OR sternal). The references of the relevant articles, including review studies, were also hand-searched in an attempt to identify additional potentially eligible trials. No limitation on the year of publication was set. 


\section{Abbreviations and Acronyms \\ $\mathrm{CDC}=$ Centers for Disease Control \\ $\mathrm{CI}=$ confidence interval \\ GCS $=$ gentamicin collagen sponge \\ $\mathrm{RCT}=$ randomized controlled trial \\ $\mathrm{RR}=$ risk ratio \\ SWI $=$ sternal wound infection}

\section{Study Selection}

Literature search and study selection were independently performed by 2 investigators (M.N.M., P.K.M.). To be eligible, a study should be an RCT, evaluate GCS use in patients undergoing cardiac surgery, and assess the effectiveness of GCS. Both blinded and open-label trials were considered eligible. There were no language restrictions. Unpublished studies reported as abstracts in conferences were searched but not included in this review. $^{14}$

\section{Data Extraction}

Data extraction was independently performed by 2 investigators (M.N.M., P.K.M.); any disagreement was resolved by consensus in meetings with all investigators. Data were extracted regarding the study design (methodology, exclusion criteria, follow-up), patient population and characteristics, preoperative and perioperative variables (antibiotic prophylaxis, operation performed), and reported outcomes of each trial (any SWI, deep SWI, superficial SWI, surgically treated SWI, mortality). A quality assessment of the reviewed trials was also performed using the modified Jadad criteria; studies with a score of 3 or more were considered of high quality. ${ }^{15}$

\section{Analyzed Outcomes: Definitions}

The primary outcomes for this review were deep SWI and any SWI (defined as the total of deep and superficial SWI). Superficial SWI, surgically treated SWI, and mortality comprised secondary outcomes. All analyses were performed on the per-protocol populations (patients who met all inclusion and exclusion criteria, received the intervention, and had complete follow-up data).

SWI was defined according to the Centers for Disease Control and Prevention (CDC)/National Healthcare Safety Network criteria ${ }^{16}$; briefly, it refers to a sternal infection occurring within 1 month and related to the operation, which may involve only the skin and subcutaneous tissue of the incision (superficial SWI) or extend to the fascia and muscle layers (deep SWI). Infections involving organ space (ie, mediastinitis) were considered deep SWI.

\section{Statistical Methods}

The statistical analyses were performed with Review Manager (RevMan), version 5.1 (Copenhagen: the Nordic Cochrane Centre, the Cochrane Collaboration, 2011). Statistical heterogeneity between studies was assessed by using a chi-square test and $\mathrm{I}^{2}$; a $P$ value less than .10 for the chi-square test or $\mathrm{I}^{2}$ greater than $50 \%$ indicated significant heterogeneity. Publication bias was not assessed because of the small number of included trials. ${ }^{17}$ Pooled risk ratios (RRs) and $95 \%$ confidence intervals (CIs) were calculated for dichotomous variables (ie, SWI) using the DerSimonianLaird random effects model. ${ }^{18}$ Statistical significance was set at $P<.05$.

\section{RESULTS}

The search process generated 188 studies, of which 17 were considered potentially eligible. After detailed evaluation, 4 RCTs (enrolling 4844 patients undergoing cardiac surgery) were included in the meta-analysis (Figure 1). The methodology and patient characteristics of the reviewed trials are shown in Table 1.

\section{Trial Design and Quality Assessment}

Two trials were single-center (in Finland and Germany), ${ }^{8,13} 1$ trial was 2 -center (in Sweden), ${ }^{7}$ and 1 trial was multicenter (48 centers in the United States). ${ }^{9}$ Two trials had a double-blind design, ${ }^{7,13}$ and 2 trials had

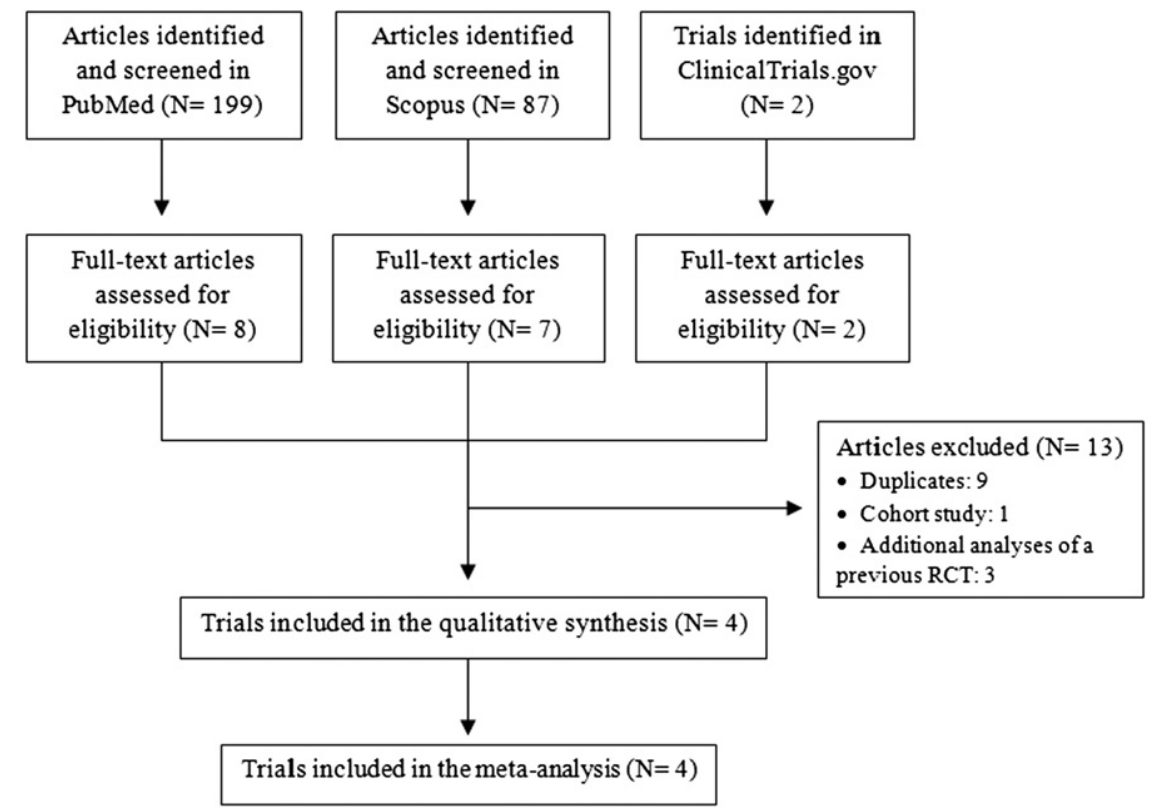

FIGURE 1. Flow diagram of reviewed studies. No additional articles were identified through hand searching. RCT, Randomized controlled trial. 
TABLE 1. Methodology and patient characteristics of the reviewed trials

\begin{tabular}{|c|c|c|c|c|c|c|}
\hline Trial & Trial quality* & Trial population $\dagger$ & $\begin{array}{c}\text { Intervention (per- } \\
\text { protocol population) } \dagger\end{array}$ & Antibiotic prophylaxis & 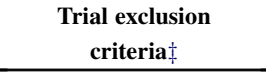 & $\begin{array}{l}\text { Within-trial differences } \\
\text { among compared arms }\end{array}$ \\
\hline $\begin{array}{l}\text { Friberg and } \\
\quad \text { colleagues } \\
\text { Sweden }\end{array}$ & DC DB RCT [4] & $\begin{array}{l}2000 \text { patients } \\
\text { Elective and emergency } \\
\text { cardiac and ascending } \\
\text { aorta surgery } \\
\text { FU: } 2 \text { mo }\end{array}$ & $\begin{array}{l}2 \times \text { GCS }(\text { not } \\
\text { premoistened) } \\
\text { containing } 260 \mathrm{mg} \\
\text { gentamicin vs no } \\
\text { sponge [ } 983 \text { vs 987] }\end{array}$ & $\begin{array}{l}\text { Oxacillin } \\
\text { Cloxacillin } \\
\text { Mouthwash (in } 1 \text { center) } \\
\text { No nasal antibiotics }\end{array}$ & $\begin{array}{l}\text { Aminoglycosides within } \\
2 \mathrm{wk}\end{array}$ & $\begin{array}{l}\text { Intervention: more likely } \\
\text { to have received aspirin } \\
\text { preoperatively and to } \\
\text { undergo CABG } \\
\text { Control: more likely to } \\
\text { have received oral } \\
\text { steroids preoperatively }\end{array}$ \\
\hline $\begin{array}{l}\text { Eklund and } \\
\text { colleagues }^{8} \\
\text { Finland }\end{array}$ & $\begin{array}{l}\text { SC RCT [3] } \\
\text { Surgeon-blinded }\end{array}$ & $\begin{array}{l}542 \text { patients } \\
\text { Elective CABG } \\
\text { FU: } 3 \text { mo }\end{array}$ & $\begin{array}{l}\text { GCS (premoistening NR) } \\
\text { containing } 130 \mathrm{mg} \\
\text { gentamicin vs no } \\
\text { sponge [269 vs 269] }\end{array}$ & $\begin{array}{l}\text { Cefuroxime }(85 \%) \\
\text { Cefuroxime }+ \\
\quad \text { vancomycin }(15 \%)\end{array}$ & $\begin{array}{l}\text { Severe renal insufficiency } \\
\text { (uremia or need for } \\
\text { dialysis) or previous } \\
\text { kidney transplant/redo } \\
\text { procedure }\end{array}$ & $\begin{array}{l}\text { The compared arms were } \\
\text { balanced. }\end{array}$ \\
\hline $\begin{array}{l}\text { Bennett-Guerrero } \\
\text { and colleagues }{ }^{9} \\
\text { USA }\end{array}$ & $\begin{array}{l}\text { MC RCT [3] } \\
\text { Patient-blinded }\end{array}$ & $\begin{array}{l}1502 \text { patients } \\
\text { Elective CABG and } \\
\quad \text { valvuloplasty } \\
\text { FU: } 3 \text { mo }\end{array}$ & $\begin{array}{l}2 \times \text { GCS (premoistened) } \\
\text { containing } 260 \mathrm{mg} \\
\text { gentamicin vs no } \\
\text { sponge [ } 727 \text { vs } 733 \text { ] }\end{array}$ & $\begin{array}{l}\text { Cefazolin }(53 \%) \\
\text { Cefuroxime }(24 \%) \\
\text { Vancomycin }(30 \%) \\
\text { Ciprofloxacin }(2 \%) \\
\text { Nasal mupirocin }(48 \%) \\
\text { Chlorhexidine shower } \\
\quad(89 \%) \\
\text { Mouthwash }(30 \%)\end{array}$ & $\begin{array}{l}\text { Only adult patients at high } \\
\text { risk for infection } \\
\text { (obese or diabetic) } \\
\text { were enrolled. } \\
\text { Concomitant surgery/ } \\
\text { preoperative cardiac } \\
\text { mechanical assistance } \\
\text { device/systemic } \\
\text { infection/ } \\
\text { aminoglycosides } \\
\text { within } 2 \text { wk/renal } \\
\text { insufficiency (serum } \\
\text { creatinine }>3 \text { mg/dL } \\
\text { or need for dialysis)/ } \\
\text { major organ } \\
\text { transplantation, } \\
\text { malignancy, or } \\
\text { immuno- } \\
\text { suppression/significant } \\
\text { drug or alcohol abuse/ } \\
\text { life expectancy }<3 \text { mo }\end{array}$ & $\begin{array}{l}\text { The compared arms were } \\
\text { balanced. }\end{array}$ \\
\hline $\begin{array}{l}\text { Schimmer and } \\
\text { colleagues }^{13} \\
\text { Germany }\end{array}$ & SC DB RCT [4] & $\begin{array}{l}800 \text { patients } \\
\text { Elective and emergency } \\
\quad \text { CABG and } \\
\quad \text { valvuloplasty } \\
\text { FU: } 1 \text { mo }\end{array}$ & $\begin{array}{l}\text { GCS (not premoistened) } \\
\text { containing } 130 \mathrm{mg} \\
\text { gentamicin vs placebo } \\
\text { sponge [353 vs 367] }\end{array}$ & Cefuroxime & $\begin{array}{l}\text { Preexisting osteitis/ } \\
\text { immunosuppression }\end{array}$ & $\begin{array}{l}\text { Control: more likely to be } \\
\text { female, to have } \\
\mathrm{LVEF}<30 \% \text { and } \\
\text { higher preoperative } \\
\text { serum creatinine, and } \\
\text { to undergo } \\
\text { a reoperation }\end{array}$ \\
\hline
\end{tabular}

$\overline{D C}$, Dual-center; $D B$, double-blind; $R C T$, randomized controlled trial; $F U$, follow-up; $G C S$, gentamicin collagen sponge; $C A B G$, coronary artery bypass grafting; $S C$, singlecenter; $N R$, not reported; $M C$, multicenter $L V E F$, left ventricular ejection fraction. *Trial quality assessment was performed following the modified Jadad criteria for RCTs. The score is reported in brackets. ${ }^{15} \dagger$ Trial population refers to the number of patients enrolled in each trial. The compared per-protocol patient arms are reported in brackets in the "Intervention" column. †ॄ Exclusion criteria not reported in the table but pertaining to all reviewed trials comprised hypersensitivity to gentamicin, inability to communicate or obtain informed consent, or participation in another ongoing trial and pregnancy/lactation (apart from the trial of Eklund and colleagues ${ }^{8}$ ).

a single-blind design (1 was surgeon-blind ${ }^{8}$ and 1 was patient-blind $\left.{ }^{9}\right)$. Proper allocation concealment through a placebo collagen sponge was performed in only 1 trial $^{13}$; all other trials used no sponge in the control arm. All RCTs were considered of high quality (range, 3-4, according to the Jadad criteria). All 4 trials reported sponsoring by the GCS manufacturers.

Two trials enrolled patients undergoing CABG or valvuloplasty, ${ }^{9,13} 1$ trial enrolled only patients undergoing $\mathrm{CABG}^{8}$, and 1 trial enrolled patients undergoing a variety of cardiac or ascending aorta operations ${ }^{7} ; 2$ trials included both elective and emergency operations, ${ }^{7,13}$ whereas the remaining 2 excluded patients undergoing emergency operations. ${ }^{8,9}$ The mean follow-up of the trials was 2.25 months (range, 1-3 months). Two trials used GCSs containing $130 \mathrm{mg}$ of gentamicin in the intervention arm, ${ }^{8,13}$ whereas the other 2 trials used 2 sponges in each patient (260 mg gentamicin). ${ }^{7,9}$ The GCS was reported to be premoistened in normal saline in 1 trial. ${ }^{9}$ In all trials, intravenous prophylactic antibiotics were administered preoperatively ( $<60$ minutes from surgery) and discontinued within 48 hours; diagnosis of SWI was established using the CDC criteria in all trials. 


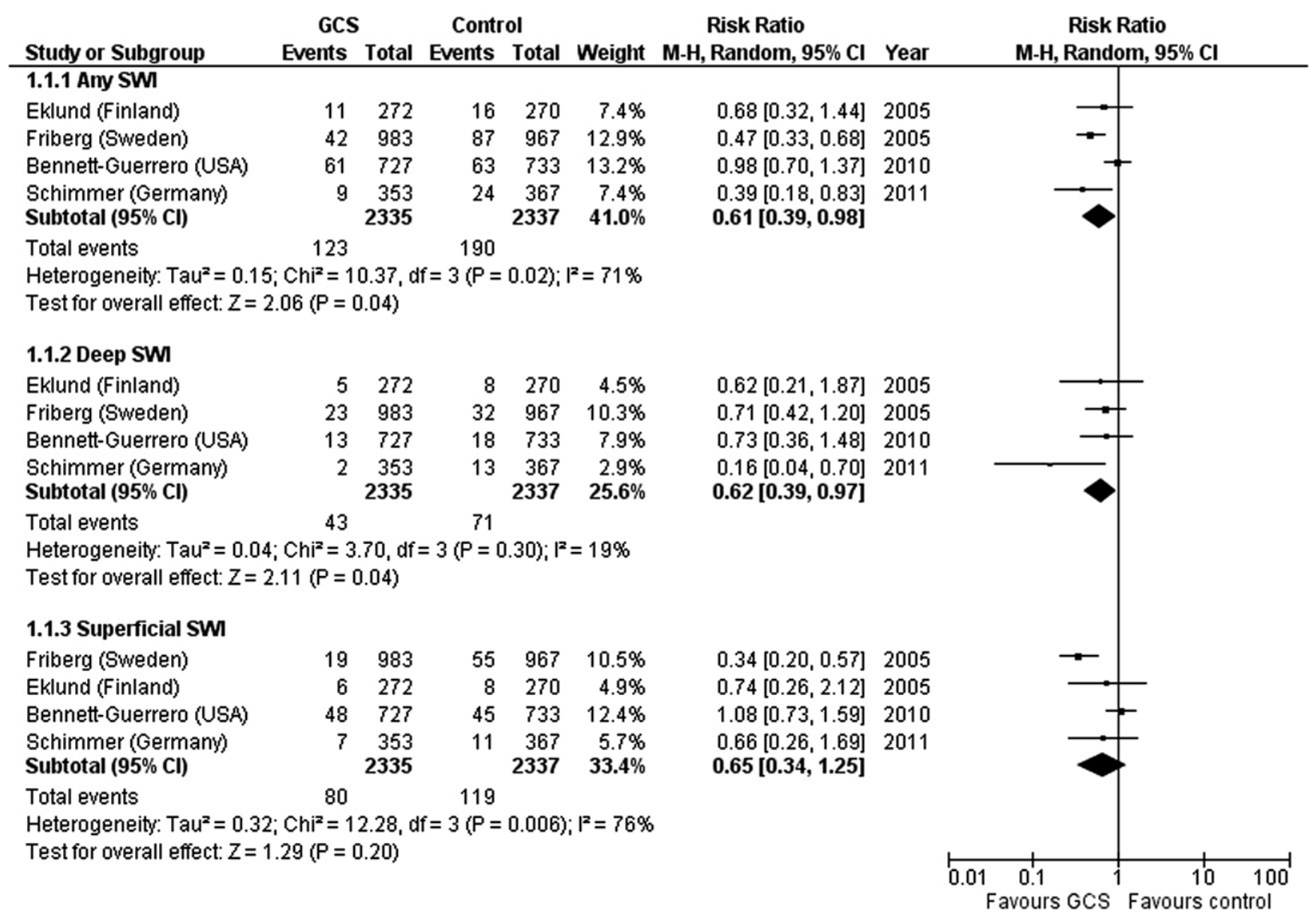

FIGURE 2. Forest plots depicting the RRs of SWI for GCS versus control (vertical line = "no difference" point between the 2 regimens; squares = risk ratios; diamonds $=$ pooled RRs for all RCTs; horizontal lines $=95 \% \mathrm{CI}$ ). GCS, Gentamicin collagen sponge; $M$ - $H$, Mantel-Heinzel; $C I$, confidence interval; $S W I$, sternal wound infection; $d f$, degrees of freedom.

\section{Primary and Secondary Outcomes}

All trials reported on the deep SWI rate. By pooling data from the 4 trials (4672 patients), GCS use seemed to significantly reduce deep SWI rate (RR, 0.62; 95\% CI, 0.39-0.97; $P=.04$ ) (Figure 2). The same pattern was evident when any SWI was considered; by pooling data from the 4 trials (4672 patients), the RR was 0.61 (95\% CI, 0.39-0.98; $P=.04)$ (Figure 2).

With regard to superficial SWI rate, GCS use demonstrated no benefit ( 4 trials, 4672 patients; RR, 0.65 ; $95 \%$ CI, 0.34-1.25; $P=.20$ ) (Figure 2). Although only 2 trials (3410 patients) provided data on surgically treated SWI, GCS use seemed beneficial (RR, 0.59; 95\% CI, 0.41$0.86 ; P=.005)$. In regard to all-cause mortality, when data from 3 trials (3994 patients) were pooled, no difference was demonstrated between the 2 arms (RR, $0.90 ; 95 \%$ CI, $0.57-1.42 ; P=.66)$.

The extracted data on the primary and secondary outcomes of the reviewed trials are presented in Table 2. The most commonly isolated pathogens among patients with a SWI were gram-positive cocci; specifically, coagulasenegative Staphylococcus spp and Staphylococcus aureus grew in $43 \%(83 / 193)$ and $28 \%(54 / 193)$ of all positive cultures, respectively. Gram-negative bacteria were responsible for 23\% (44/193) of positive cultures (Table 2).

\section{DISCUSSION}

The main finding of this meta-analysis, pooling data provided by 4 published RCTs with a total of 4672 per-protocol patients, is that the incidence of deep SWI after cardiac surgery among patients treated with implantable GCSs was significantly lower compared with controls. Specifically, the probability for deep SWI to occur in the control arm was 1.6 times higher than the corresponding probability in the GCS arm. It should be noted that this difference was significant at a level of $4 \%$ using a random effects model. No difference was noted for superficial wound infections, but the overall wound infection rate was significantly lower in the GCS arm. Our findings suggest that the application of GCSs perioperatively may be beneficial in preventing postoperative SWIs in patients undergoing cardiac surgery.

We used the random effects model in all analyses because of the observed statistical heterogeneity. SWI rates in the control arms of all trials were comparable (deep SWI, $2.5 \%-3.5 \%$; any SWI, $5.9 \%-9 \%$; superficial SWI, $3 \%-6.1 \%$ ). At large, the observed statistical heterogeneity 
TABLE 2. Reported outcomes in the reviewed trials (gentamicin collagen sponge vs control, as assessed in the per-protocol population)

\begin{tabular}{|c|c|c|c|c|c|c|}
\hline Trial & Any SWI & Deep SWI & Superficial SWI & $\begin{array}{l}\text { SWI treated } \\
\text { surgically }\end{array}$ & $\begin{array}{c}\text { Mortality } \\
\text { (end of follow-up) }\end{array}$ & Isolated pathogens (no., \%) \\
\hline $\begin{array}{l}\text { Friberg and colleagues }{ }^{7} \\
\text { Sweden }\end{array}$ & $\begin{array}{l}4.3 \% \text { vs } 9 \% \\
(P<.001)\end{array}$ & $\begin{array}{l}2.3 \% \text { vs } 3.3 \% \\
(P=.2)\end{array}$ & $\begin{array}{l}1.9 \% \text { vs } 5.7 \% \\
(P<.001)\end{array}$ & $\begin{array}{l}2.1 \% \text { vs } 3.9 \% \\
(P=.02)\end{array}$ & $\begin{array}{l}1.9 \% \text { vs } 1.8 \% \\
(P=.8)\end{array}$ & $\begin{array}{l}\text { CoNS 44/102 }(43 \%), \\
\text { S aureus } 28(27 \%) \text {, gram- } \\
\text { negative } 5(5 \%) \text {, other (or } \\
\text { multimicrobial) } 25(25 \%)\end{array}$ \\
\hline $\begin{array}{l}\text { Eklund and colleagues }{ }^{8} \\
\text { Finland }\end{array}$ & $\begin{array}{l}4 \% \text { vs } 5.9 \% \\
(P=.2)\end{array}$ & $\begin{array}{l}1.9 \% * \text { vs } 3 \% * \\
(P=.4)\end{array}$ & $\begin{array}{l}2.2 \% \text { vs } 3 \% \\
(P=.6)\end{array}$ & NR & $\begin{array}{l}1.1 \% \text { vs } 0.4 \% \\
(P=.6)\end{array}$ & $\begin{array}{l}\text { CoNS } 13 / 17(76 \%), S \text { aureus } \\
\quad 3(18 \%), \text { E faecalis } 2 \\
(12 \%) .\end{array}$ \\
\hline $\begin{array}{l}\text { Bennett-Guerrero and } \\
\text { colleagues }^{9}\end{array}$ & $\begin{array}{l}8.4 \% \text { vs } 8.6 \% \\
(P=.9)\end{array}$ & $\begin{array}{l}1.8 \% \text { vs } 2.5 \% \\
(P=.4)\end{array}$ & $\begin{array}{l}6.6 \% \text { vs } 6.1 \% \\
(P=.7)\end{array}$ & $\begin{array}{l}3.2 \% \text { vs } 4.9 \% \\
(P=.09)\end{array}$ & $\begin{array}{l}2.6 \% \text { vs } 3.6 \% \\
(P=.2)\end{array}$ & $\begin{array}{l}\text { CoNS } 13 / 59(22 \%), S \text { aureus } \\
22(37 \% \text {, including } 6\end{array}$ \\
\hline USA & & & & & & $\begin{array}{l}\text { MRSA isolates }(10 \%), \\
\text { E faecalis } 2(3 \%), \text { gram- } \\
\text { negative } 37(63 \%) \text {, other } 8 \\
(14 \%)\end{array}$ \\
\hline $\begin{array}{l}\text { Schimmer and colleagues }{ }^{13} \\
\text { Germany }\end{array}$ & $\begin{array}{l}2.5 \% \text { vs } 6.5 \% \\
(P=.1)\end{array}$ & $\begin{array}{l}0.6 \% \text { vs } 3.5 \% \\
(P=.01)\end{array}$ & $\begin{array}{l}2 \% \text { vs } 3 \% \\
(P=.5)\end{array}$ & NR & $2.5 \%$ & $\begin{array}{c}\text { CoNS } 13 / 15(87 \%), S \text { aureus } \\
1(7 \%), P \text { acnes } 2(13 \%), \\
\text { gram-negative } 2(13 \%) \dagger\end{array}$ \\
\hline
\end{tabular}
stinitis or osteitis developed were in the deep SWI group. †Refers to the patients in whom deep SWI developed.

is mostly attributed to the unexpectedly high rate of superficial SWI in the GCS arm of the US trial (6.6\%), raising an issue of superficial SWI misdiagnosis. ${ }^{9}$ However, trial investigators reported an apparently proper infection diagnosis protocol, using 3 blinded infectious disease specialists in a clinical event committee and standardized criteria, including those from the $\mathrm{CDC}^{16}$ and the ASEPSIS scoring system (a scoring system based on need for Additional treatment, the presence of Serious discharge, Erythema, Purulent exudate, and Separation of the deep tissues, the Isolation of bacteria, and the duration of inpatient Stay). ${ }^{19}$

Some have argued that the US trial's negative results may be associated with the practice of premoistening the GCS by dipping it in normal saline before implantation ${ }^{11}$; none of the other trials have reported such practice. However, this explanation seems unlikely taking into account that the patients' serum gentamicin levels in the US trial were similar to those in the Swedish trial. Patients enrolled in the US trial were all considered at risk for SWI (obese, diabetic patients), in contrast with the other 3 trials; this is also unlikely to have contributed to the nonappearance of benefit in the GCS arm, especially because relevant data from the Swedish trial underline the benefit of GCSs in this group of patients. ${ }^{7}$

It has also been highlighted that gram-negative pathogens were implicated in a significant proportion of SWI in the US trial $(63 \%$ vs $0 \%-13 \%$ in the other trials). By taking into account that skin flora mostly consist of gram-positive cocci, especially of the Staphylococcus spp, this may raise concerns that patients' SWI was not acquired perioperatively, but postoperatively. ${ }^{12}$ In addition, the unique pharmacokinetic/pharmacodynamic properties of aminoglycosides may account for a difference in the efficacy of gentamicin against gram-positive versus gram-negative pathogens ${ }^{20}$ in the setting of local administration via a collagen sponge. In general, gentamicin is active against various gram-positive and gram-negative bacteria, such as Staphylococcus spp (including methicillin-resistant $S$ aureus), Escherichia coli, Klebsiella pneumoniae, Enterobacter spp, Pseudomonas aeruginosa, and Acinetobacter spp; however, resistant strains have developed and disseminated. ${ }^{20,21}$

A common finding among all reviewed trials was the relatively high incidence of postoperative SWI (2.5\%-9\%). Although numerous modalities (preoperative topical antiseptics, eradication of $S$ aureus carriage, intravenous prophylaxis, topical application of antibiotics, and others) have been tried, the SWI rate has not decreased significantly. ${ }^{2}$ In regard to antibiotic prophylaxis, there are reports underlining that surgeons' self-reported practice does not conform to the existing guidelines: In an international survey, $26 \%$ of cardiac surgeons did not administer the prophylaxis within 60 minutes of the incision, and $14 \%$ continued the administration even after postoperative day $4 .^{22}$ In addition, it has been claimed that the standard antimicrobials used may need to be reconsidered in this era of advancing antimicrobial resistance. ${ }^{21,23}$ Furthermore, differences in the antimicrobial formulations used (ie, generic vs original cefuroxime) may have an impact on the development of SWI. ${ }^{24}$ Other strategies that may aid in reducing SWI rates include strict glucose management, nasopharyngeal decontamination with mupirocin, skin decontamination with chlorhexidine showers, and topical application of antibiotics (ie, bacitracin or vancomycin) postoperatively. ${ }^{25,26}$

\section{Study Limitations}

The results of this study should be considered in view of several limitations. First, only 4 trials were identified and 
pooled; however, all trials had a large sample size, resulting in a pooled sample size of 4672 per-protocol patients, and were of high quality. Second, there was considerable statistical heterogeneity among the trials ( 2 reported a significant benefit with GCS use, and 2 reported no difference) and, to a lesser degree, clinical heterogeneity: Two trials used 1 sponge (Table 1, $130 \mathrm{mg}$ gentamicin), and 2 trials used 2 sponges ( $260 \mathrm{mg}$ gentamicin); it should be noted that only 1 study using $130 \mathrm{mg}$ and 1 study using $260 \mathrm{mg}$ of gentamicin have managed to demonstrate a significant reduction of SWI. This is a relatively new intervention, and dosing and application technique need to be standardized. Last, patients enrolled in each trial received different antibiotic prophylaxis regimens (Table 1).

\section{CONCLUSIONS}

Despite the limitations of this meta-analysis, it provides evidence to support the use of GCSs for the prevention of postoperative SWIs in patients undergoing cardiac surgery. Synthesis of the available evidence, provided by 4 published RCTs with a total of 4672 patients who had rather conflicting results, showed that the incidence of postoperative deep SWI among patients undergoing cardiac surgery treated with GCSs was significantly lower compared with controls. However, additional large, high-quality RCTs are warranted to further elucidate this field.

The authors thank Dr Schimmer for the provision of additional data regarding the microbiological outcomes in one of the trials. ${ }^{13}$

\section{References}

1. Friberg O, Dahlin LG, Levin LA, et al. Cost effectiveness of local collagengentamicin as prophylaxis for sternal wound infections in different risk groups. Scand Cardiovasc J. 2006;40:117-25.

2. Mauermann WJ, Sampathkumar P, Thompson RL. Sternal wound infections. Best Pract Res Clin Anaesthesiol. 2008;22:423-36.

3. Tang GH, Maganti M, Weisel RD, Borger MA. Prevention and management of deep sternal wound infection. Semin Thorac Cardiovasc Surg. 2004;16: $62-9$.

4. Rosmarakis ES, Prapas SN, Rellos K, Michalopoulos A, Samonis G, Falagas ME. Nosocomial infections after off-pump coronary artery bypass surgery: frequency, characteristics, and risk factors. Interact Cardiovasc Thorac Surg. 2007;6:759-67.

5. Falagas ME, Rosmarakis ES, Rellos K, Michalopoulos A, Samonis G, Prapas SN. Microbiologically documented nosocomial infections after coronary artery bypass surgery without cardiopulmonary bypass. $J$ Thorac Cardiovasc Surg. 2006;132:481-90.

6. Michalopoulos A, Geroulanos S, Rosmarakis ES, Falagas ME. Frequency, characteristics, and predictors of microbiologically documented nosocomial infections after cardiac surgery. Eur J Cardiothorac Surg. 2006;29:456-60.
7. Friberg O, Svedjeholm R, Soderquist B, Granfeldt H, Vikerfors T, Kallman J. Local gentamicin reduces sternal wound infections after cardiac surgery: a randomized controlled trial. Ann Thorac Surg. 2005;79:153-62.

8. Eklund AM, Valtonen M, Werkkala KA. Prophylaxis of sternal wound infections with gentamicin-collagen implant: randomized controlled study in cardiac surgery. J Hosp Infect. 2005;59:108-12.

9. Bennett-Guerrero E, Ferguson TB Jr, Lin M, et al. Effect of an implantable gentamicin-collagen sponge on sternal wound infections following cardiac surgery: a randomized trial. JAMA. 2010;304:755-62.

10. Horvath KA. Local antibiotics to prevent surgical site infections: another Zeno's paradox? Arch Surg. 2011;146:359-60.

11. Corn T. Treating sternal wound infections after cardiac surgery with an implantable gentamicin-collagen sponge. JAMA. 2010;304:2123; author reply 4.

12. Friberg O, Svedjeholm R, Soderquist B. Treating sternal wound infections after cardiac surgery with an implantable gentamicin-collagen sponge. JAMA. 2010; 304:2123-4; author reply 4.

13. Schimmer C, Ozkur M, Sinha B, et al. Gentamicin-collagen sponge reduces sternal wound complications after heart surgery: a controlled, prospectively randomized, double-blind study. J Thorac Cardiovasc Surg. 2012;143: 194-200.

14. Rosmarakis ES, Soteriades ES, Vergidis PI, Kasiakou SK, Falagas ME. From conference abstract to full paper: differences between data presented in conferences and journals. FASEB J. 2005;19:673-80.

15. Moher D, Pham B, Jones A, et al. Does quality of reports of randomised trials affect estimates of intervention efficacy reported in meta-analyses? Lancet. 1998;352:609-13.

16. Horan TC, Andrus M, Dudeck MA. CDC/NHSN surveillance definition of health care-associated infection and criteria for specific types of infections in the acute care setting. Am J Infect Control. 2008;36:309-32.

17. Egger M, Davey Smith G, Schneider M, Minder C. Bias in meta-analysis detected by a simple, graphical test. BMJ. 1997;315:629-34.

18. DerSimonian R, Laird N. Meta-analysis in clinical trials. Control Clin Trials. 1986;7:177-88.

19. Wilson AP, Weavill C, Burridge J, Kelsey MC. The use of the wound scoring method 'ASEPSIS' in postoperative wound surveillance. J Hosp Infect. 1990; 16:297-309.

20. Pagkalis S, Mantadakis E, Mavros MN, Ammari C, Falagas ME. Pharmacological considerations for the proper clinical use of aminoglycosides. Drugs. 2011; 71:2277-94.

21. Maraki S, Mavros MN, Kofteridis DP, Samonis G, Falagas ME. Epidemiology and antimicrobial susceptibility of 536 multidrug-resistant Gram-negative bacilli isolated from patients treated in surgical wards. Surg Infect (Larchmt). 2012 (in press).

22. Alexiou VG, Ierodiakonou V, Peppas G, Falagas ME. Antimicrobial prophylaxis in surgery: an international survey. Surg Infect (Larchmt). 2010;11: 343-8.

23. Falagas ME, Alexiou VG, Peppas G, Makris GC. Do changes in antimicrobial resistance necessitate reconsideration of surgical antimicrobial prophylaxis strategies? Surg Infect (Larchmt). 2009;10:557-62.

24. Mastoraki E, Michalopoulos A, Kriaras I, et al. Incidence of postoperative infections in patients undergoing coronary artery bypass grafting surgery receiving antimicrobial prophylaxis with original and generic cefuroxime. J Infect. 2008;56: 35-9.

25. MacIver RH, Stewart R, Frederiksen JW, Fullerton DA, Horvath KA. Topical application of bacitracin ointment is associated with decreased risk of mediastinitis after median sternotomy. Heart Surg Forum. 2006;9:E750-3.

26. Vander Salm TJ, Okike ON, Pasque MK, et al. Reduction of sternal infection by application of topical vancomycin. J Thorac Cardiovasc Surg. 1989;98: 618-22. 